\title{
PHYSIOLOGICAL RESPONSES OF THREE WOODY SPECIES SEEDLINGS UNDER WATER STRESS, IN SOIL WITH AND WITHOUT ORGANIC MATTER ${ }^{1}$
}

\author{
Maria da Assunção Machado Rocha ${ }^{2 *}$, Claudivan Feitosa de Lacerda ${ }^{3}$, Marlos Alves Bezerra $^{4}$, Francisca \\ Edineide Lima Barbosa ${ }^{2}$, Hernandes de Oliveira Feitosa ${ }^{5}$ and Carlos Henrique Carvalho de Sousa ${ }^{6}$

\footnotetext{
${ }^{1}$ Received on 07.01.2015 accepted for publication on 03.03.2016.

${ }^{2}$ Universidade Federal do Ceará, Programa de Pós-Graduação em Solos e Nutrição de Plantas, Fortaleza, Ceará - Brasil. E-mail:<assunrocha@gmail.com>and<edineidelb@gmail.com>.

${ }^{3}$ Universidade Federal do Ceará, Centro de Ciências Agrárias, Departamento de Engenharia Agrícola, Fortaleza, CE - Brasil. E-mail: <cfeitosa@ufc.br>.

${ }^{4}$ Empresa Brasileira de Pesquisa Agropecuária, Centro Nacional de Pesquisa de Agroindústria Tropical, Fortaleza, Ceará Brasil. E-mail: <marlos.bezerra@embrapa.br>.

${ }^{5}$ Universidade Federal do Ceará, Programa de Pós-Graduação em Engenharia Agrícola, Fortaleza, Ceará - Brasil. E-mail: $<$ hernandes.oliveira@gmail.com>.

${ }^{6}$ Universidade Federal do Ceará, Doutorado em Engenharia Agrícola, Fortaleza, Ceará - Brasil. E-mail: <sousaibiapina@yahoo.com.br>.

*Corresponding author.
}

\begin{abstract}
The low availability of water in the soil is one of the limiting factors for the growth and survival of plants. The objective of this study was to evaluate the responses of physiological processes in early growth of guanandi (Calophyllum brasilense Cambess), African mahogany (Khayai vorensis A. Chev) and oiti (Licaniato mentosa Benth Fritsch) over a period of water stress and other of rehydration in the soil with and without addition of organic matter. The study was conducted in a greenhouse and the experimental design was completely randomised into a $3 \times 2 \times 2$ factorial scheme, comprising three species (guanandi, African mahogany, and oiti), two water regimes (with and without water restriction) and two levels of organic fertilisation (with and without the addition of organic matter). Irrigation was suspended for 15 days in half of the plants, while the other half (control) continued to receive daily irrigation, the soil being maintained near field capacity for these plants. At the end of the stress period, the plants were again irrigated for 15 days to determine their recovery. Water restriction reduced leaf water potential and gas exchange in the three species under study, more severely in soil with no addition of organic matter. The addition of this input increased soil water retention and availability to the plants during the suspension of irrigation, reducing the detrimental effects of the stress. During the period of rehydration, there was strong recovery of water status and leaf gas exchange. However recovery was not complete, suggesting that some of the effects caused by stress irreversibly affected cell structures and functions. However, of the species being studied, African mahogany displayed a greater sensitivity to stress, with poorer recovery.
\end{abstract}

Keywords: Organic fertilization; Water deficit; Gas exchange.

\section{RESPOSTAS FISIOLÓGICAS DE MUDAS DE TRÊS ESPÉCIES LENHOSAS SOB ESTRESSE HÍDRICO, EM SOLO COM E SEM MATÉRIA ORGÂNICA}

\begin{abstract}
RESUMO - A baixa disponibilidade de água no solo é um dos fatores mais limitantes para o crescimento e sobrevivência das plantas. O objetivo deste trabalho foi avaliar as respostas dos processos fisiológicos na fase inicial do crescimento do guanandi (Calophyllum brasilense Cambess), mogno africano (Khayaivorensis A. Chev) e oiti (Licania tomentosa Benth Fritsch) durante um periodo de estresse hídrico e outro de reidratação, em solo com e sem adição de matéria orgânica. O experimento foi conduzido em casa de vegetação, em delineamento experimental inteiramente casualizado, em arranjo fatorial $3 \times 2 \times 2$, sendo composto por três espécies (guanandi, mogno africano e oiti), dois regimes hídricos (com e sem restrição hídrica) e dois níveis de fertilização orgânica (com e sem adição de matéria orgânica). A irrigação foi suspensa por 15 dias em metade das plantas, enquanto que a outra metade (controle) recebeu irrigação continuamente. Ao final do período de estresse, as plantas voltaram a ser irrigadas durante 15 dias para a determinação da
\end{abstract}


recuperação. A suspensão da irrigação reduziu o potencial hidrico e as trocas gasosas foliares das três espécies estudadas, sendo que os efeitos foram menores nas plantas que receberam adição de matéria orgânica por esta promover maior retenção de umidade no solo. No período de reidratação, ocorreu forte recuperação do estado hídrico e das trocas gasosas foliares. Porém, a recuperação não foi completa, indicando que parte dos efeitos causados pelo estresse atingiu as estruturas e funções celulares de forma irreversível. Dentre as espécies estudadas, o mogno africano apresentou a maior sensibilidade ao estresse, com menor recuperação.

Palavras-chave: Fertilização orgânica; Déficit hídrico; Trocas gasosas.

\section{INTRODUCTION}

Water deficit is considered to be one of the main environmental factors that induce change in various physiological and biochemical processes (MANAVALAN et al., 2009). When the amount of water in the soil decreases, the water potential of the plants is reduced as a result of the greater resistance to water flow in the soil-plant-atmosphere system. The water potential of the plant reaches very low values due to a reduction in the availability of water in the soil, and the plant is no longer able to extract water (PAIVA, OLIVEIRA, 2006), placing many restrictions on the metabolic processes of the plants (FLEXAS et al., 2007).

The first response of almost all plants to water stress is closing of the stomata in order to avoid an excessive loss of water through transpiration, since a reduction in stomatal conductance allows a greater conservation of water without completely compromising metabolic activity (HU et al., 2010; SENGUPTA et al., 2011). This strategy aims at maintaining the water status of the leaf, so as to reduce the detrimental effects of low soil water availability (INMAM-BAMBER; SMITH, 2005).

The recovery of turgor is an important component of the plant response to water stress, however after such extreme weather events as the long periods of drought in semi-arid regions, the plants may become impaired, requiring prolonged periods of recovery and leaving them more vulnerable to further extremes of climate (GUTSCHICK; BASSIRIRAD, 2003). It is worth noting that such responses vary depending on the adaptive capacity of the species, and on strategies for conserving water in the soil.

The addition of organic matter increases water retention in the soil, and therefore has the potential to reduce the detrimental effects of the lack of rain, especially in the early stages of development in perennial species, stages that are the most affected by water shortage.

Revista Árvore, Viçosa-MG, v.40, n.3, p.455-464, 2016
Morphological adaptation of the plants to drought ensures maximum water absorption under conditions of water stress, and allows for the growth or survival of the species. Studies that assess the capacity of plant species to recover after periods of water stress are therefore very relevant (PINHEIRO; CHAVES, 2011), given that knowledge of the mechanisms of adaptation and recovery from water stress in plants ensures the appropriate choice of species for each region.

Based on the above, the aim of the present work was to evaluate the responses of physiological processes during the early growth stage of the guanandi (Calophyllum brasilense Cambess), the African mahogany (Khayai vorensis A. Chev) and the oiti (Licaniato mentosa Benth Fritsch), to a period of water stress and another of rehydration, in a soil with and without the addition of organic matter.

\section{MATERIALAND METHODS}

The study took place from April to June 2013 in the experimental area of the Weather Station of the Department of Agricultural Engineering at the Federal University of Ceará (UFC) in Fortaleza, in the State of Ceará, Brazil, and was carried out in a gabletype greenhouse consisting of an aluminium frame and a polyethylene cover with aluminet, aligned in an east-west direction.

According to the Köppen classification (1948), the local climate is type Aw', rainy tropical, very hot, with a predominance of rainfall in the summer and autumn, which corresponds to the period from February to May.

The soil used was classified as a Red-Yellow Argisol (EMBRAPA, 2013), and has the following chemical characteristics: $\mathrm{pH}$ (water) $=5.1,10 \mathrm{mg} \mathrm{P} \mathrm{kg}^{-1}, 8.69$ $\mathrm{g} \mathrm{OM} \mathrm{kg}^{-1}, 4.01 \mathrm{cmol} \mathrm{kg}^{-1} \mathrm{CEC}, 62 \% \mathrm{~V}$, and 1.30, 1.20, $0.17,1.82,0.35,0.19 \mathrm{cmol}_{\mathrm{c}} \mathrm{kg}^{-1} \mathrm{Ca}^{2+}, \mathrm{Mg}^{2+}, \mathrm{K}^{+}, \mathrm{H}^{+}+\mathrm{Al}^{3+}$, $\mathrm{Al}^{3+}$ and $\mathrm{Na}^{+}$respectively. 
Pots with a capacity of $5 \mathrm{~kg}$ were used in the study, of which half were filled with a mixture of soil and organic matter (earthworm humus) in the ratio of 2:1 (soil with organic matter - WOM) and the other half only with soil (soil with no organic matter - NOM). After being mixed with the humus in the above ratio, the soil displayed the following chemical characteristics: $\mathrm{pH}$ (water) $=$ $6.9,144 \mathrm{mg} \mathrm{P} \mathrm{kg}^{-1}, 21.41 \mathrm{~g} \mathrm{OM} \mathrm{kg}^{-1}, 11.61 \mathrm{cmol} \mathrm{kg}^{-1} \mathrm{CEC}$

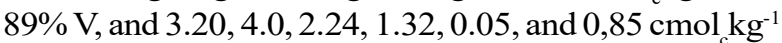
$\mathrm{Ca}^{2+}, \mathrm{Mg}^{2+}, \mathrm{K}^{+}, \mathrm{H}^{+}+\mathrm{Al}^{3+}, \mathrm{Al}^{3+}$ and $\mathrm{Na}^{+}$respectively.

The experimental design was completely randomised into a $3 \times 2 \times 2$ factorial scheme, comprising three species: guanandi - Calophyllum brasiliense Cambes, African mahogany - Khayai vorensis A. Cheve and oiti Licaniato mentosa Benth Fritsch, two water regimes (with and without water restriction) and two levels of organic fertilisation (with and without the addition of organic matter).

Four-month old, certified seedlings were purchased from a nursery. After transplanting, they were irrigated daily for eight days for acclimatisation in the greenhouse. Irrigation was then suspended for 15 days in half of the plants, while the other half (control) continued to receive daily irrigation, the soil being maintained near field capacity for these plants. At the end of the stress period, the plants were again irrigated for 15 days to determine their recovery; the experiment lasted for 30 days.

Gravimetric soil moisture and leaf water potential were measured after 15 days of stress and again after 15 days of recovery. The gravimetric soil moisture was determined following a methodology from EMBRAPA(1997). The leaf water potential was measured in whole plants, between the hours of 4 and 5 in the morning, using a Scholandertype pressure pump (SCHOLANDER et al., 1965).

Measurements of gas exchange were taken at the end of each period, i.e. 15 days after irrigation was suspended and again after 15 days of rehydration; the following variables were obtained: stomatal conductance $(g s)$, rate of transpiration $(E)$ and net rate of photosynthesis $(A)$. These measurements were made between 0930 and 1030 on the first fully mature leaf from the apex with the aid of an infrared gas analyser (IRGA, LI-6400XT, Licor, USA) coupled to an artificial source of radiation with an intensity of $1500 \mu \mathrm{mol} \mathrm{m}^{-2}$ $\mathrm{s}^{-1}$, under natural conditions of air temperature and $\mathrm{CO}_{2}$ concentration.
To analyse the stress period, the results were submitted to analysis of variance at $1 \%$ and $5 \%$ probability using the Assistat 7.7 BETA software (SILVA; AZEVEDO, 2009). Mean values between the effects of the single factors and the interactions were compared by Tukey's test at 5\% probability. For comparative analysis of the periods of stress and recovery, the mean values of the repetitions and the standard error of the mean were used.

\section{RESULTS}

Analysis of variance of the data during the stress period showed a significant effect for the single factors, and for the interaction between the factors of water regime and organic fertilisation, on the variables of soil moisture, leaf water potential and stomatal conductance (Table 1). Considering analysis of the single effects, it was found that the suspension of irrigation affected plant water status and gas exchange, whereas the application of organic matter positively favoured these variables.

There was a significant effect on soil moisture from the interaction between the factors water regime $\mathrm{x}$ organic fertilisation (Figure 1). The greatest values for moisture were obtained with the irrigated soil, so that suspending irrigation caused a reduction in soil water availability. However, the addition of organic matter resulted in higher levels of soil moisture in both the irrigated and non-irrigated soil during the stress period (Figure 1A) and in the recovery phase (Figure 1B).

It was found that leaf water potential differed between plants with and without a water restriction, with a reduction from -0.42.MPa to -1.13.MPa for the treatment with organic matter, and from $-0.43 \mathrm{MPa}$ to $-3.88 \mathrm{MPa}$ for plants that did not receive this input (Figure 2A). It was also found that the presence of organic matter only interfered with the leaf water potential of those plants with a water restriction.

Comparing the values for water potential before and after the recovery period, it was found that plants of the guanandi (Figure 2B), oiti (Figure 2C) and African mahogany (Figure 2D) almost completely recovered their water status. However, values remained slightly more negative in plants where irrigation was suspended during the stress phase, especially those which did not received organic fertiliser.

Revista Árvore, Viçosa-MG, v.40, n.3, p.455-464, 2016 
Table 1 - Summary of analysis of variance for soil moisture $(\theta)$, water potential $(\Psi \mathrm{w})$, stomatal conductance (gs), rate of transpiration (E) and net rate of photosynthesis in three species for water regime and organic fertiliser during the period of stress.

Tabela 1-Resumo da análise de variância para unidade do solo $(\theta)$ potencial hídrico ( $\Psi w)$, condutância estomática ( $g s)$, taxa de transpiração $(E)$ e taxa de fotossíntese liquida em três espécies vegetais, em função do regime hídrico e da adubação orgânica no período de estresse.

\begin{tabular}{|c|c|c|c|c|c|c|}
\hline \multirow[t]{2}{*}{ FV } & \multirow[t]{2}{*}{ GL } & \multicolumn{5}{|c|}{ QM } \\
\hline & & $\theta$ & $\Psi_{\mathrm{W}}$ & $g s$ & $E$ & $A$ \\
\hline $\operatorname{Species}(\mathrm{A})$ & 2 & $5.60591 \mathrm{~ns}$ & $17.86861 * *$ & $0.00922 * *$ & $3.22990 *$ & $2.25342 \mathrm{~ns}$ \\
\hline $\mathrm{WR}(\mathrm{B})$ & 1 & $1395.27151 * *$ & $3902.08444 * *$ & $0.18341 * *$ & $128.65662 * *$ & $343.43461 * *$ \\
\hline OM. (C) & 1 & $807.12810 * *$ & $1722.25000 * *$ & $0.03733 * *$ & $20.36884 * *$ & $42.38249 * *$ \\
\hline$A \times B$ & 2 & $29.41514 *$ & $1.57194 \mathrm{~ns}$ & $0.00591 *$ & $1.57442 \mathrm{~ns}$ & $3.08440 \mathrm{~ns}$ \\
\hline$A \times C$ & 2 & $3.96490 \mathrm{~ns}$ & $5.82750 \mathrm{~ns}$ & $0.00070 \mathrm{~ns}$ & $0.11235 \mathrm{~ns}$ & $2.67681 \mathrm{~ns}$ \\
\hline $\mathrm{B} \times \mathrm{C}$ & 1 & $41.77468 *$ & $1697.44000 * *$ & $0.1239 * *$ & $1.52555 \mathrm{~ns}$ & $1.96006 \mathrm{~ns}$ \\
\hline$A \times B \times C$ & 2 & $14.48658 \mathrm{~ns}$ & $2,29750 \mathrm{~ns}$ & $0.00027 \mathrm{~ns}$ & $0.10252 \mathrm{~ns}$ & $0.23019 \mathrm{~ns}$ \\
\hline Treatment & 11 & 213.73812 & 670.62778 & 0.02412 & 14.59904 & 36.75153 \\
\hline Residue & 24 & 7.69978 & 3.82944 & 0.00149 & 0.75097 & 1.82240 \\
\hline Total & 35 & & & & & \\
\hline $\mathrm{CV} \%$ & & 21.04 & 13.34 & 32.54 & 23.00 & 27.76 \\
\hline \multicolumn{7}{|l|}{ Species } \\
\hline Guanandi & & $13.70 \mathrm{a}$ & $-1.36 a$ & $0.096 \mathrm{a}$ & $3.25 \mathrm{a}$ & $4.64 a$ \\
\hline A.Mahogany & & $13.44 \mathrm{a}$ & $-1.44 a b$ & $0.081 \mathrm{ab}$ & $2.96 \mathrm{ab}$ & $3.96 \mathrm{a}$ \\
\hline Oiti & & $12.41 \mathrm{a}$ & $-1.61 b$ & $0.072 \mathrm{~b}$ & $2.39 \mathrm{~b}$ & $3.88 \mathrm{a}$ \\
\hline \multicolumn{7}{|l|}{ WR } \\
\hline NWR & & $19.41 \mathrm{a}$ & $-0.43 a$ & $0.122 \mathrm{a}$ & $4.11 \mathrm{a}$ & $6.63 a$ \\
\hline WWR & & $6.96 \mathrm{a}$ & $-2.51 b$ & $0.044 b$ & $1.62 b$ & $1.69 \mathrm{~b}$ \\
\hline \multicolumn{7}{|l|}{ OM. } \\
\hline WOM & & $17.02 \mathrm{a}$ & $-0.78 a$ & $0.103 \mathrm{a}$ & $3.45 \mathrm{a}$ & $5.16 \mathrm{a}$ \\
\hline NOM & & $8.45 b$ & $-2.16 b$ & $0.060 \mathrm{~b}$ & $2.29 b$ & $3.16 \mathrm{~b}$ \\
\hline
\end{tabular}

**, * e ns: significant at $1 \%$, significant at $5 \%$ and not significant by Tukey's test respectively.

Stomatal conductance was negatively affected by the suspension of irrigation in the three species under study (Figure 3A). In relative terms, the reductions were $78 \%, 77 \%$ and $70 \%$ for the guanandi, oiti and African mahogany respectively, comparing the non-irrigated plants with those that received continuous irrigation. Moreover, it was found that the application of organic matter favoured stomatal opening both in the irrigated plants and those with no irrigation (Figure 3B).

The values for stomatal conductance, and the net rates of photosynthesis between the periods of stress and recovery for the three species are compared in Figure 4. It was found that there was a recovery of $g_{s}$ values in plants that had been subjected to water stress. However, values remained lower than those seen in plants that were irrigated continuously.

The results also showed that between the nonirrigated plants, the African mahogany (Figure 4C) displayed less recovery compared to the guanandi (Figure 4A) and oiti (Figure 4B).

Revista Árvore, Viçosa-MG, v.40, n.3, p.455-464, 2016
The rates of photosynthesis decreased with the suspension of irrigation, especially in plants that did not receive organic matter (Figure 4). Comparing the plants that received organic matter, it was found that the suspension of irrigation caused reductions in carbon assimilation of the order of $66 \%, 63 \%$ and $55 \%$ in the guanandi (Figure 4D), oiti (Figure 4E) and African mahogany (Figure 4F) respectively. For plants that did not receive this input, the decrease caused by the water stress was even greater, reaching reductions of $86 \%, 89 \%$ and $91 \%$ respectively.

Despite the strong impact on the rates of photosynthesisof suspending irrigation, recovery was good for all species after the period of rehydration (Figure 4), however values in the plants under continuous irrigation remained even higher.

After the recovery period, plants of the guanandi, oiti and African mahogany that received organic matter and had previously been under stress displayed values for rates of photosynthesis approximately $28 \%$, 

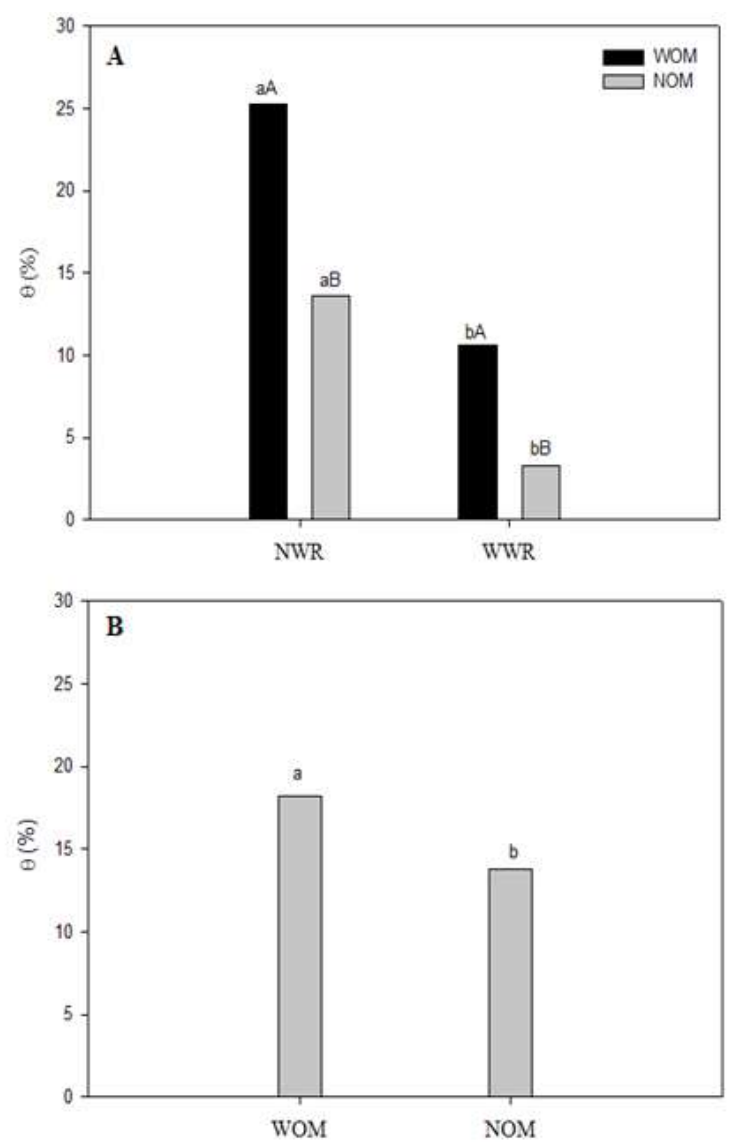

Figure 1 - Soil water content as a function of water regime and organic fertiliser during the period of stress (A) and at the end of recovery (B). In figure A, mean values followed by the same lowercase letter for water regime and uppercase letter for organic fertiliser do not differ by Tukey's test at 5\% probability. NWR - No water restriction; WWR - with water restriction; WOM - with organic matter; NOM - no organic matter.

Figura 1 - Umidade gravimétrica do solo em função do regime hídrico e da adubação orgânica no periodo de estresse (A) e ao final do periodo de recuperação (B). Na figura A as médias seguidas da mesma letra minúscula, para regime hídrico, e maiúscula, para adubação orgânica, não diferem entre si pelo teste de Tukey, a 5\% de probabilidade. NWR - sem restrição hídrica; WWR-com restrição hídrica; WOM - com matéria orgânica; NOM-sem matéria orgânica.

$20 \%$ and $39 \%$ lower than in plants under irrigation, whereas for those plants that did not receive organic matter, the decrease caused by water stress was even greater, reaching reductions of $34 \%, 23 \%$, and $35 \%$ respectively.

\section{DISCUSSION}

The reduction in soil water availability (Figure 1) due to the suspension of irrigation caused a decrease in leaf water potential (Figure 2), probably as a result of the greater resistance to water flow created in the soil-plant-atmosphere system (TAIZ; ZEIGER, 2013), and the reduction in soil water extraction (PAIVA; OLIVEIRA, 2006). According to Carvalho (2005), the suspension of irrigation causes an abrupt reduction in values for water potential measured at dawn.

The capacity for water retention of the organic matter resulted in greater soil water content during the suspension of irrigation, favouring maintenance of the water status of the plants which received this input. It was found that at the beginning of the experiment, the soil with organic matter had $21.41 \mathrm{~g} \mathrm{OM} \mathrm{kg}^{-1}$ and by the end of the experiment, $23.69 \mathrm{~g} \mathrm{OM} \mathrm{kg}^{-1}$, while the soil with no organic matter had $8.49 \mathrm{~g} \mathrm{OM} \mathrm{kg}^{-1}$ at the start of the experiment and $10.55 \mathrm{~g} \mathrm{OM} \mathrm{kg}^{-1}$ at the end.

The addition of organic matter to the soil favours water retention, a characteristic which is also determined by the texture and structure of the soil (MINASNY; MCBRATNEY, 2007). In the present study, a soil of a clayey-loam texture was used that hardened when dried, so that the addition of organic matter increased the levels of moisture in both the irrigated soil and the soil where irrigation was suspended (Figure 1).

The main physical characteristic of the soil to be affected by organic matter is aggregation, which indirectly affects other physical characteristics such as density, porosity, aeration, infiltration and water retention capacity (RESCK et al., 2008; SANTOS et al., 2008).

In the soil with no organic matter, there was greater water restriction with prolonged stress, so that water transport in the soil-plant-atmosphere system was reduced with decreases in the hydraulic conductivity of the soil, the supply of water to the roots becoming limited, restricting the $g_{s}, E$ and $A$ (Table 1, Figures 3 and 4). It is important to note that the rates of gas exchange depend on soil moisture, as well as on deep rooting, the density of absorbing roots and the environmental conditions (MANZONI et al., 2013). 

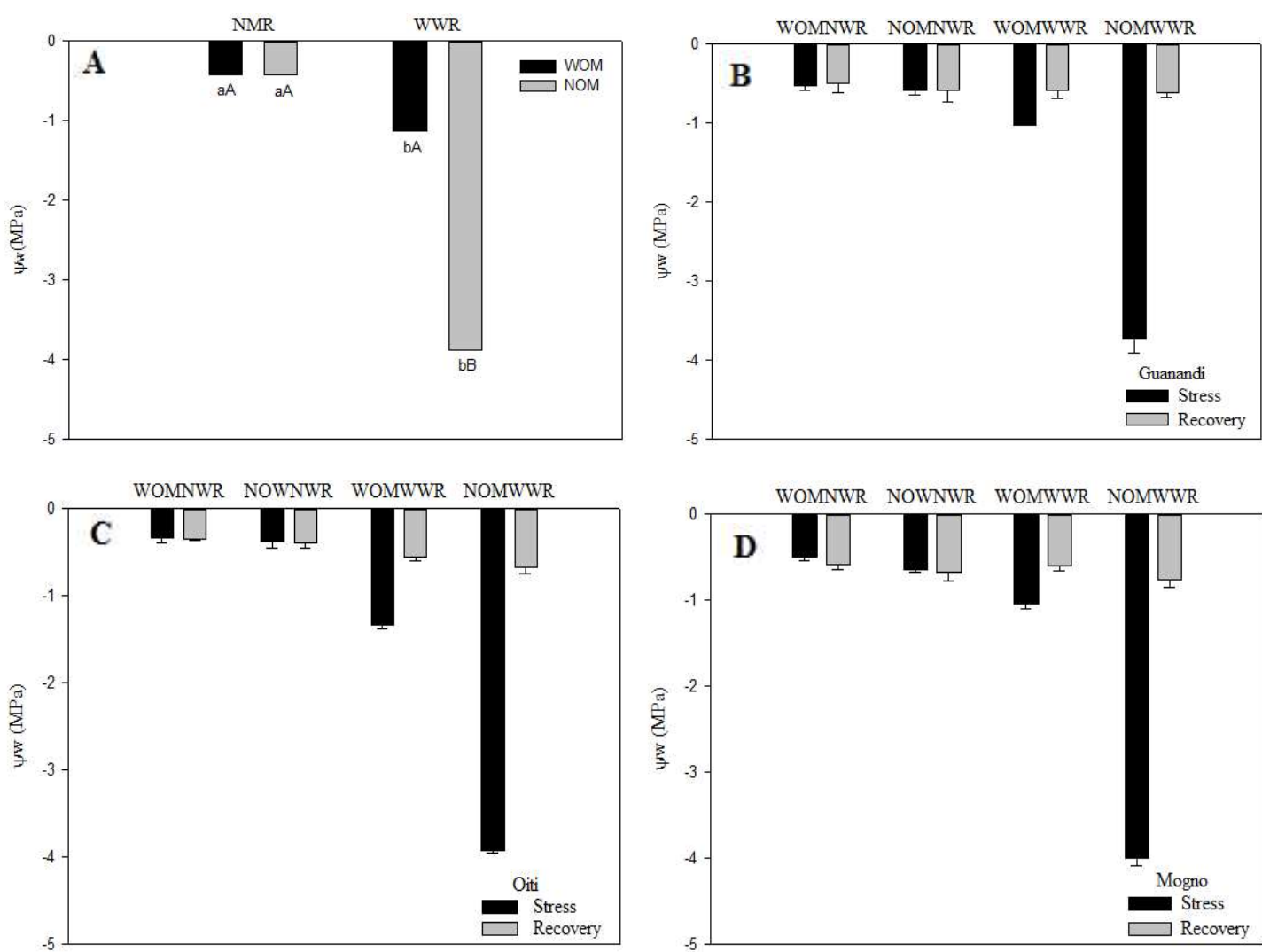

Figure 2 - Leaf water potential as a function of water stress and organic fertiliser (A), and comparison of the values between the periods of stress and recovery in plants of guanandi (B), oiti (C) and African mahogany (D). In figure A, mean values followed by the same lowercase letter for water regime and uppercase letter for organic fertiliser do not differ by Tukey's test at 5\% probability. In the remaining figures, each value represents the mean value of three replications $(n=3)$ and its standard error $( \pm S E)$. WOMNWR- soil with organic matter and no water restriction; NOMNWR- no organic matter and no water restriction; WOMWWR - soil with organic matter and with water restriction; NOMWWR- no organic matter and with water restriction.

Figura 2 - Potencial hídrico foliar em função do regime hídrico e da adubação orgânica no período de estresse (A) e comparação dos valores em plantas de guanandi (B), oiti (C) e mogno africano (D) entre os períodos de estresse e de recuperação. Na figura A as médias seguidas pelas mesmas letras minúsculas, para regime hídrico, e maiúsculas, para adubação orgânica, não diferem entre si pelo teste de Tukey, a 5\% de probabilidade. Para as demais figuras, cada valor representa a média de três repetições $(n=3)$ e o erro padrão da média $( \pm S E)$. WOMNWR - solo com matéria orgânica sem restrição hidrica; NOMNWR - solo sem matéria orgânica sem restrição hídrica; WOMWWR - solo com matéria orgânica com restrição hídrica; NOMWWR - solo sem matéria orgânica com restrição hídrica.

Under the conditions of a limited supply of water from the soil, inhibition of photosynthesis occurred due to closing of the stomata, which is the first protection mechanism of the plant for preventing excessive water loss and maintaining turgor (HU et al., 2010). Silva et al. (2008) found that a more severe water deficit reduced transpiration in stressed plants.

Closing of the stomata is probably a response to the accumulation of ABA in the leaves due to the reduction in leaf water potential (CHAVES et al., 2009).
Conversely, the increase in water retention caused by the organic matter favoured stomatal opening and carbon assimilation in plants where irrigation was suspended, as these physiological processes are very sensitive to water deficit (PINHEIRO; CHAVES, 2011).

The inhibitory effects of water stress on photosynthesis are generally associated with the low absorption of $\mathrm{CO}_{2}$ (FLEXAS et al., 2008) caused by limitations on diffusion due to stomatal closure (ZHOU, YU, 2010), or by changes in biochemical reactions during 

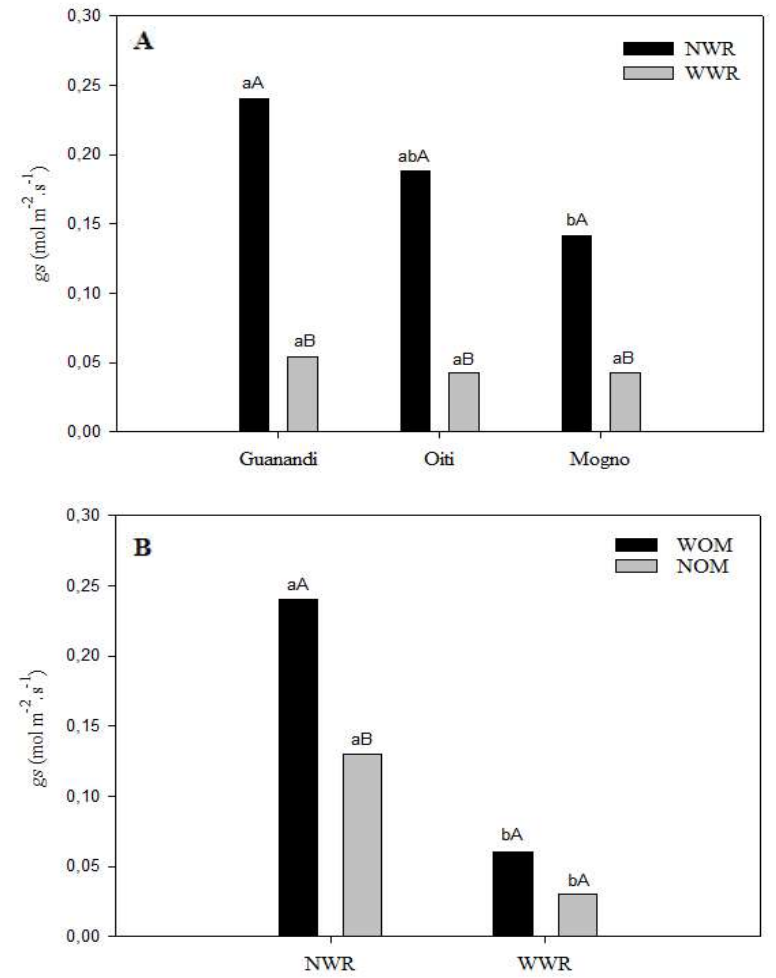

Figure 3 - Stomatal conductance in three species for water regime (A) and organic fertiliser (B) during the period of stress. In figure A, mean values followed by the same lowercase letter for species and uppercase letter for water regime do not differ by Tukey's test at $5 \%$ probability. In figure B, mean values followed by the same lowercase letter for water regime and uppercase letter for organic fertiliser do not differ by Tukey's test at $5 \%$ probability. NWR - No water restriction; WWR - with water restriction; WOM - with organic matter; NOM - no organic matter.

Figura 3 - Condutância estomática em três espécies em função do regime hídrico (A) e da adubação orgânica (B) no periodo de estresse. Na figura A médias seguidas pelas mesmas letras minúsculas, para espécies, e maiúsculas, para regime hídrico, não diferem entre si pelo teste de Tukey, a 5\% de probabilidade. Na figura B médias seguidas pelas mesmas letras minúsculas, para regime hídrico e maiúsculas para adubação orgânica, não diferem entre si pelo teste de Tukey, a 5\% de probabilidade. $N W R$-sem restrição hídrica; $W W R$-com restrição hídrica; WOM - com matéria orgânica; NOM - sem matéria orgânica.

the metabolism of $\mathrm{CO}_{2}$ assimilation (LAWLOR; TEZARA, 2009). Sensitivity of the photosynthetic processes to water stress varies according to species and the level of severity of the water stress (CHAVES et al., 2009). In fact, both a reduction in soil water availability and a reduction in stomatal conductance affect photosynthesis (THOMPSON et al., 2007; PÉREZMARTÍN et al., 2009).

Recovery of gas exchange after the period of water stress depends on the severity of the imposed stress and the intrinsic capacity of the species. In the present study, a strong recovery of the rate of gas exchange was found (Figure 4), but values remained lower than those seen in plants that had been previously irrigated. According to several authors, recovery is sometimes never complete and may take weeks, depending on the severity of the imposed stress and the capacity of each species for recovery (MIYASHITA et al., 2005; FLEXAS et al., 2007; PINHEIRO; CHAVES, 2011).

Recovery of the variables $g_{s}, E$ and $A$ after 15 days of rehydration did not show the same intensity in the three species, being lower in the African mahogany, especially for $g_{s}$. However, recovery did not reach the same level as in the irrigated plants, showing that the level of imposed stress caused irreversible alterations in leaf function and/or structure. According to Anyia and Herzog (2004), the rates of recovery of gas exchange are lower in plants submitted to severe water stress.

In coffee plants and rubber plants grown under different cropping systems during the wet and dry seasons, net photosynthesis and stomatal conductance showed significant differences between species in the rainy season, with the highest values seen in the rubber plants; in the dry season both photosynthesis and stomatal conductance were similar between species. In the rubber plants, photosynthesis and stomatal conductance were greater during the rainy season in relation to the dry season (OLIVEIRA et al., 2006).

Assessing photosynthetic characteristics in response to water stress and recovery in two cultivars of Kentucky bluegrass, it was found that the midnight cultivar recovered leaf hydration more rapidly one day after the return of irrigation, compared to the cultivar, brilliant. However, photosynthesis, stomatal conductance and transpiration had not fully recovered three days after the return of irrigation, suggesting that there had been permanent damage. The capacity for recovery after stress was different for photosynthesis and transpiration in both cultivars, the same behaviour being seen in the present work after 15 days of recovery (XU et al., 2013).

Revista Árvore, Viçosa-MG, v.40, n.3, p.455-464, 2016

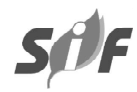



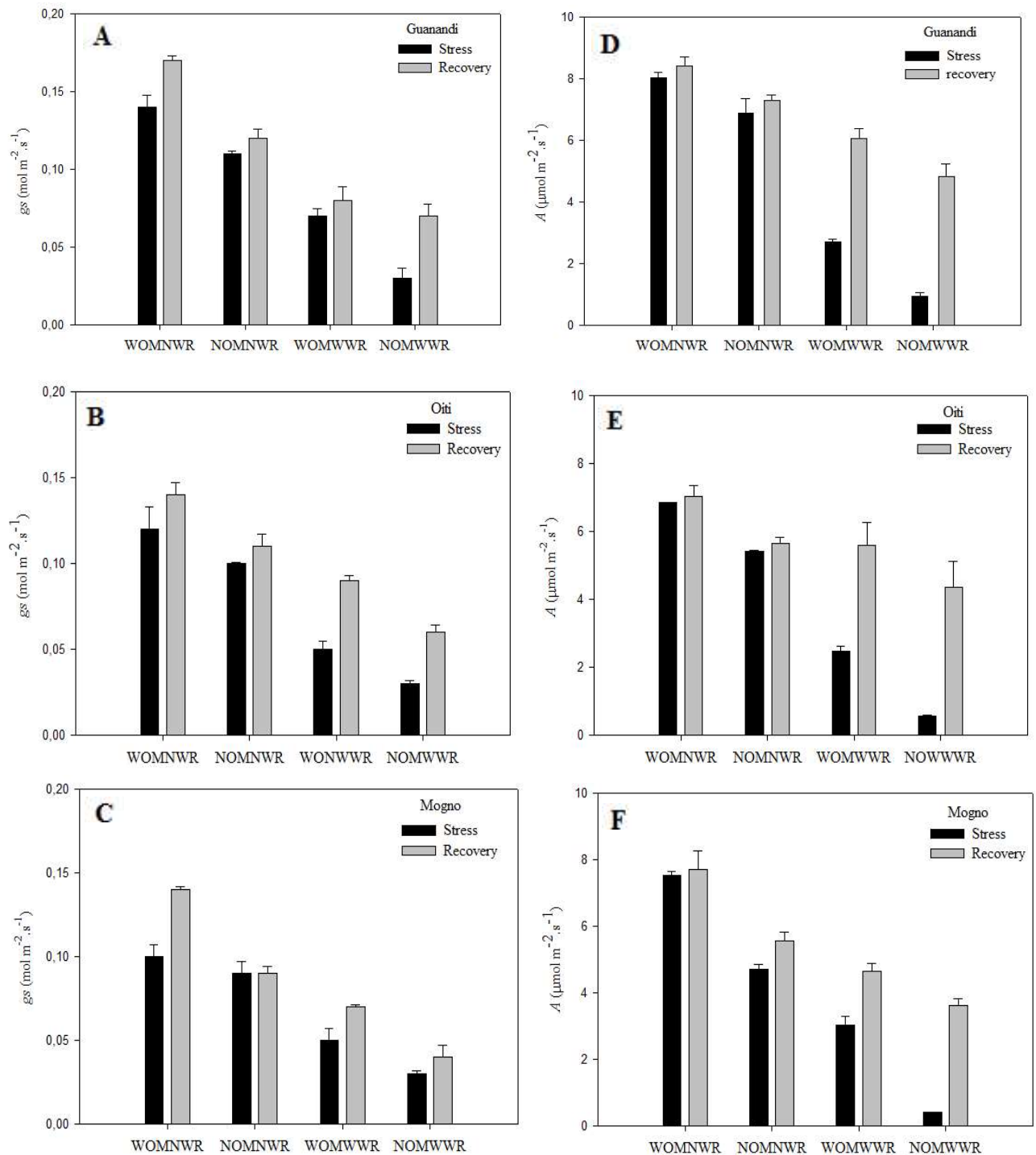

Figure 4 - Stomatal conductance and net photosynthesis in leaves of the guanandi (A and D), oiti (B and E) and African mahogany $(\mathrm{C}$ and $\mathrm{F})$ for water regime and organic fertiliser during the periods of stress and recovery. Each value represents the mean value of three replications $(n=3)$ and its standard error $( \pm S E)$. WOMNWR - soil with organic matter and no water restriction; NOMNWR- no organic matter and no water restriction; WOMWWR - soil with organic matter and with water restriction; NOMWWR- No organic matter and with water restriction.

Figura 4-Condutância estomática e taxa de fotossíntese líquida em folhas de guanandi (A e D), oiti (B e E) e mogno africano (C e F) em função do regime hídrico e da adubação orgânica no período de estresse e recuperação. Cada valor representa a média de três repetições $(n=3)$ e o erro padrão da média $( \pm S E)$.WOMNWR - solo com matéria orgânica sem restrição hídrica; NOMNWR - solo sem matéria orgânica sem restrição hídrica; WOMWWR - solo com matéria orgânica com restrição hídrica; NOMWWR - solo sem matéria orgânica com restrição hídrica.

\section{CONCLUSION}

Water restriction reduced leaf water potential and gas exchange in the three species under study, more severely in soil with no addition of organic matter.
The addition of this input increased soil water retention and availability to the plants during the suspension of irrigation, reducing the detrimental effects of the stress. 
During the period of rehydration, there was strong recovery of water status and leaf gas exchange. However recovery was not complete, suggesting that some of the effects caused by stress irreversibly affected cell structures and functions. However, of the species being studied, African mahogany displayed a greater sensitivity to stress, with poorer recovery.

\section{ACKNOWLEDGMENT}

The authors wish to thank CNPq for the scholarship granted to the lead author. Thanks are also due to INCTSal and CNPq for their financial support of this work.

\section{REFERENCES}

ANYIA, A.O.; HERZOG, H. Genotypic variability in drought performance and recovery in cowpea under controlled environment. Journal of Agronomy and Crop Science, v.190, n.2 p.151-159, 2004.

CARVALHO, C.J. R.Respostas de plantas de Schizolobiumamazonicum [S.

parahybavar.amazonicum] e Schizolobiumparahyba [Schizolobiumparahybum] à deficiência hídrica. Revista Árvore, v.29, n.6, p.907-914, 2005.

CHAVES, M.; FLEXAS, J.; PINHEIRO, C. Photosynthesis under drought and salt stress: regulation mechanisms from whole plant to cell, Annals of Botany, v. 103, p.551-560, 2009.

EMPRESA BRASILEIRA DE PESQUISA AGROPECUARIA - EMBRAPA. Centro Nacional de Pesquisa de Solos. Novo sistema brasileiro de classificação dos solos. Brasília: 2013.

\section{EMPRESA BRASILEIRA DE PESQUISA} AGROPECUARIA - EMBRAPA. Centro Nacional de Pesquisa de solos. Manual de métodos de análise do solo. $2^{\text {a }}$. ed. Rio de Janeiro: 1997. 212p.

FLEXAS, J.; DIAZ-ESPEJO, A.; GALMÉS, J.; KALDENHOFF, R.; MEDRANO, H.; RIBASCARBO, M. Rapid variations of mesophyll conductance in response to changes in $\mathrm{CO} 2$ concentration around leaves, Plant Cell and Environment, v.30, p.1284-1298, 2007.

FLEXAS, J.; RIBAS-CARBÓ, M.; DIAZ-ESPEJO, A.; GALMÉS, J.; MEDRANO, H. Mesophyll conductance to $\mathrm{CO} 2$ : current knowledge and future prospects. Plant Cell and Environment, v. 31, p.602-62 1, 2008.

GUTSCHICK, V.P.; BASSIRIRAD, H. Extreme events as shaping physiology, ecology, and evolution of plants: toward a unified definition and evaluation of their consequences. New Phytologist, v.160, n.1, p.1-21, 2003.

HU, L.; WANG, Z.; HUANG, B. Diffusion limitations and metabolic factors associated with inhibition and recovery of photosynthesis from drought stress in aC3 perennial grass species. Physiologia Plantarum, v.139, n.1, p.93-106, 2010.

INMAN-BAMBER, N.G.; SMITH, D.M. Water relations in sugarcane and reposts water deficit. Field Crops Research, v.92, p.185-202, 2005.

KOPPEN, W. Climatologia. México: Fondo de Cultura Econômica, 1948. 479p.

LAWLOR, D.W.; TEZARA, W. Causes of decreased photosynthetic rate and metabolic capacity in water deficient leaf cells: a critical evaluation of mechanisms and integration of processes. Annals of Botany, v.103, p.561$579,2009$.

MANAVALAN, L.P.; GUTTIKONDA, S.K.; TRAN L.S.P.; NGUYEN, H.T.Physiological and molecular approaches to improve drought resistance in soybean. Plant and Cell Physiology, v.50, p.1260-1276, 2009.

MANZONI, S.; VICO, G.; KATUL, G.;

PORPORATO, A. Biological constraints on water transport in the soil-plant-atmosphere. Water Resource Research, v.51, p.292-304, 2013.

MINASNY, B.; MCBRATNEY, A.B. Spatial prediction of soil properties using EBLUP with a Matérn covariance function. Geoderma, v. 140, n.4, p.324-336, 2007.

MIYASHITA, K.; TANAKAMARU, S.; MAITANI, T.; KIMURA, K. Recovery responses of photosynthesis, transpiration and stomatal conductance in kidney bean following drought stress. Environmental and

Experimental Botany, v.53, p.205-214, 2005.

Revista Árvore, Viçosa-MG, v.40, n.3, p.455-464, 2016 
OLIVEIRA, C.R.M.; BARBOSA, J.P.R.A.D.; SOARES, A.M.; OLIVEIRA, L.E.M.; MACEDO, R.L.G. Trocas gasosas de cafeeiros (CoffeaarábicaL.) e seringueiras (Hevea brasiliensisMuell. Arg.) em diferentes sistemas de cultivo na região de larvas, MG. Revista Árvore, v.30, n.2, p.197-206, 2006.

PAIVA, R.; OLIVEIRA, L.M. Fisiologia e produção vegetal. Lavras: UFLA, 2006. 104p.

PÉREZ-MARTÍN, A.; FLEXAS, J.; RIBAS-CARBÓ, M.; BOTA, J.; TOMÁS, M., INFANTE, J.M.; DIAZ- ESPEJO, A. Interactive effects of soil water deficit and air vapour pressure deficit on mesophyll conductance to $\mathrm{CO} 2$ in Vitisvinifera and Oleaeuropaea. Journal of

Experimental Botany, v.60, p.2391-2405, 2009.

PINHEIRO, C.; CHAVES, M.M. Photosynthesis and drought: can we make metabolic connections from available. Journal of Experimental Botany, v.62, p.869-882, 2011.

RESCK, D.V.S.; FERREIRA, E.A.B.; FIGUEIREDO, C.C.; ZINN, Y.L. Dinâmica da Matéria Orgânica no Cerrado. In: SANTOS, G.A.; SILVA, L.S.; CANELLAS, L.P.; CAMARGO, F.O.

Fundamentos da matéria orgânica do solo: ecossistemas tropicais e subtropicais. $2^{\mathrm{a}}$. ed. Porto Alegre: Metrópole; 2008. p.359-417.

SANTOS, C.M.; VERISSIMO, V.; WANDERLEY FILHO, H.C.L.; FERREIRA, V.M.; CAVALCANTE, P.G.S.; ROLIM, E.V.; ENDRES, L. Fundamentos da matéria orgânica do solo: ecossistemas tropicais e subtropicais. $2^{\mathrm{a}}$. ed. Porto Alegre: Metropole, 2008. 654p.

SCHOLANDER, P.F.; HAMMEL, E.D.; HEMMINGSEN, E.A. Sap pressure in vacular plant. Science, v.148, p.339-346, 1965.
SENGUPTA, D.; KANNAN, M.; REDDY, A.R. A root proteomics-based insight reveals dynamic regulation of root proteins under progressive drought stress and recovery in Vignaradiata (L.) Wilczek. Planta, v.233, p.1111-1127, 2011.

SILVA, F.A.S.E.; AZEVEDO, C.A.V. Principal components analysis in the software assistatstatistical attendance. In: WORLD CONGRESS ON COMPUTERS IN AGRICULTURE, 7., New York: American Society of Agricultural and Biological Engineers, 2009

SILVA, M.A.V.; NOGUEIRA, E.J.M.C.; OLIVEIRA, A.F.M.; SANTOS, V.F. Resposta estomática e produção de matéria seca em plantas jovens de aroeira submetidas a diferentes regimes hídrico. Revista Árvore, v.32, n.2, p.335-344, 2008.

TAIZ, L.; ZEIGER, E. Fisiologia vegetal. 5.ed. Porto Alegre: Artmed, 2013.918p.

THOMPSON, A.J.; ANDREWS, J.; MULHOLLAND, B.J.; MCKEE, J.M.T.; HILTON, H.W.; HORRIDGE, J.S.; FARQUHAR, G.D.; SMEETON, R.C.; SMILLIE, I.R.A.; PRETO, C.R.; TAYLOR, I.B. Reproduction of abscisic acid in tomato increases transpiration ef?ciency and root hydraulic conductivity and in?uences leaf expansion, Plant Physiology, v.143,p.1905-1917, 2007.

XU, L.; YU, J.; HAN, L.; HUANG, B.

Photosynthetic enzyme activities and gene expression associated with drought tolerance and post-drought recovery in Kentucky bluegrass.

Environmental and Experimental

Botany, v.89, n.1, p.28-35, 2013.

ZHOU, Q.; YU, B. Changes in content of free, conjugated and bound polyamines and osmotic adjustment in adaptation of vetiver grass to water deficit. Plant Physiology and

Biochemistry, v.48, p.417-425, 2010. 